\title{
119 粒子成長方向を利用した電着銅薄膜による応力測定法 Copper Electroplating Stress Measurement Method Using Direction of Grain Growth
}

\author{
正 小畑良洋（鳥取大院）正 小野勇一（鳥取大院） \\ $\bigcirc$ 学 中尾 彰敬 (鳥取大院)
}

Yoshihiro OBATA, Yuichi ONO, Akihiro NAKAO

Tottori University, Dept. of Mechanical Engineering, Koyamacho Minami 4-101, Tottori, 680-8552 Japan

Key Words : Experimental Stress Analysis, Fatigue, Nondestructive Inspection, Copper-electroplating Method

\section{1. 緒 言}

銅めっき応力測定法(1)は，繰返し負荷を受ける機械要素に 接着した銅薄膜に発生する再結晶粒子（成長粒子）を利用し た測定法である。すなわち，薄膜に発生する成長粒子の密度 は機械要素に作用したせん断応力振幅とその繰返し数に支配 され，これらの間の構成式が実験的に導かれている(2). した がって，所定の繰返し数のもとで成長粒子の発生密度を計測 することにより，機械要素に作用したせん断応力振幅の計測 が可能となる。また，薄膜に微小な円孔を作製し，円孔縁か ら発生する成長粒子やすべり線を利用すれば，疲労強度評価 などに重要となる主応力振幅の計測も可能になることが明ら かにされている(3). しかし，この方法は二軸忍力比 $C$ (=第二 主応力 $\sigma_{2} /$ 第一主応力 $\sigma_{1}$ ) の正負により主応力を求少る基 礎式が異なるため，Cの符号を予知っておく必要がある.

ところで，成長粒子は一般に方向性を有する。これは，薄 膜に作用する最大せん断応力成分の作用方向に粒子が成長す るためであると考えられる，すなわち，粒子の成長方向は， $C$ が負となる場合は薄膜の平面内に，C五となる場合は薄 膜の厚さ方向に成長することになる，したがって，粒子の成 長方向を利用すれば, $C$ の正負の判断ができると考えられる. 以上の観点からCの符号を判定するために, 薄膜内に発生す る粒子の成長方向に着目した方法について検討した。

\section{2. 実 験 方 法}

2.1 電着銅薄膜の作製一銅薄膜は, 鏡面仕上げを施したス テンレス板に硫酸銅浴中でめっきを施した後，めっき部をス テンレス板より剥離することにより得た。薄膜の厚さは約 25 $\mu \mathrm{m}$ である.

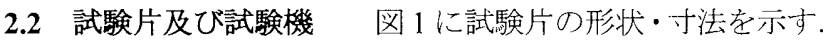
$C<0$ となる試験は，図1(a)に示すような平滑試験片を用い, 試験機にはシエンク式疲労試験機 $(60 \mathrm{~Hz})$ を使用した. $C>0$ と なる試験は，図 1(b)に示すような円板の試験片を用いた。こ れを図 2 に示す試験治具に取り付け, 電気油圧制御式疲労試 験機 $(60 \mathrm{~Hz})$ により下から円板を圧縮するようにした。なお両 試験とも，試験片素材はチタン合金であり，ひずみゲージ用 瞬間接着剤を用いて試験片に銅薄膜省接着した。

2.3 実験方法 表 1 に示す各 $C$ に対して, 試験片に作用す るせん断応力振幅 $\tau_{\max }$ と繰返し数 $N$ を種々に設定し, 繰返し 負荷試験を行った。試験終了後, 銅薄膜に電解研磨亡エッチ ング処理を行い, 光学曊微鏡にて成長粒子の画像を撮影し, 画像処理ソフトにより粒子の成長方向 $\theta$ と成長粒子発生密度 $r^{*}$ を計測した。図3に発生した成長粒子の一例を示す。

\begin{tabular}{c|c|c|c|c|c} 
Tablel Biaxial stress ratio in each experimental condition \\
\hline \hline $\begin{array}{c}\text { Machine } \\
\text { type }\end{array}$ & \multicolumn{3}{|c|}{ Shenck type } & \multicolumn{2}{c}{$\begin{array}{c}\text { Servo- } \\
\text { hydraulic }\end{array}$} \\
\hline$\theta$ or $r$ & $90^{\circ}$ & $60^{\circ}$ & $30^{\circ}$ & $10 \mathrm{~mm}$ & $0 \mathrm{~mm}$ \\
\hline$C$ & -1.0 & -0.52 & -0.16 & 0.8 & 1.0 \\
\hline
\end{tabular}

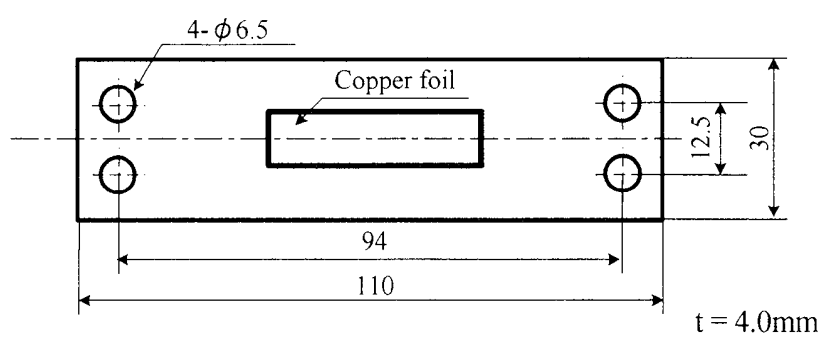

( a ) smooth specimen $(C<0)$

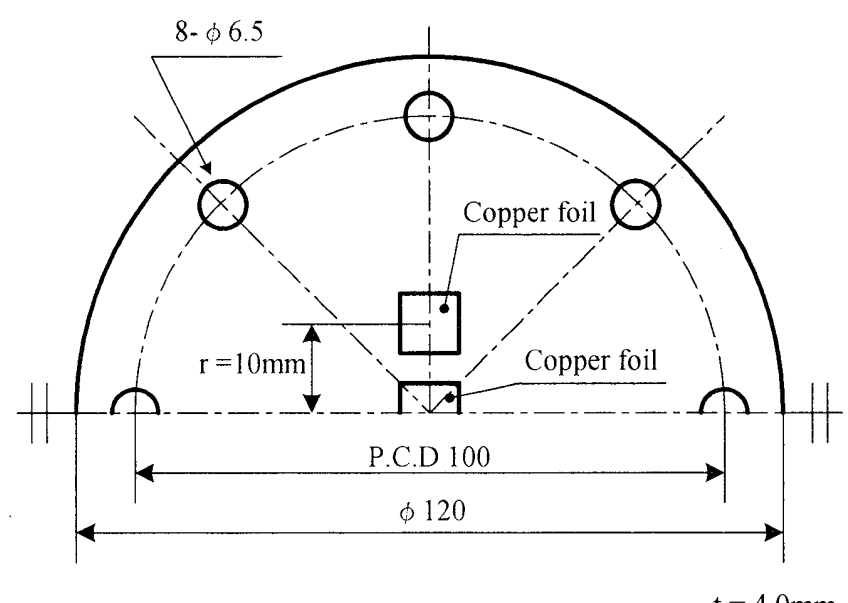

(b ) Disk type specimen ( $C>0$ )

Fig.1 Geometry and dimensions of test specimen

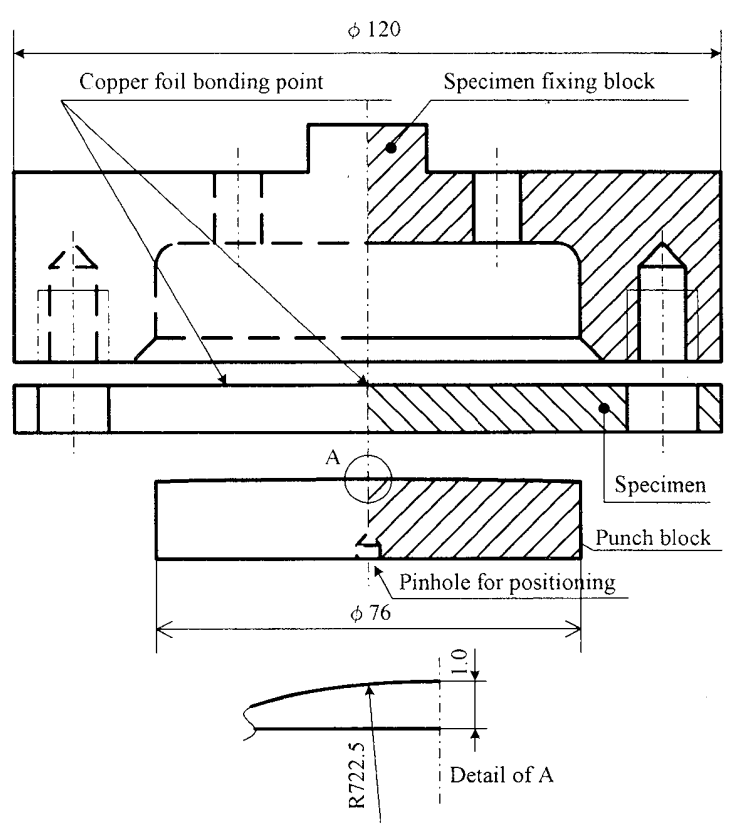

Fig.2 Axial bending of disk type specimen

日本機械学会講演論文集 No.095-1（'09-3，中国四国支部 第47期総会・講演会） 


\section{3. 実 験 結 果}

図 3 より，C<0の場合，多くの粒子が最大せん断灾力の方 向に成長し，その成長軸は $90^{\circ}$ の位相をもっていることが確 認できる，一方， $C>0$ の場合，粒子に方向性は見られるが， 成長軸の明確な位相差は確認できない，乙こで各々の条件に 対する $\theta$ の相対度数分布の一例を図 4 に示す. $C<0$ の場合, ピーク值が $90^{\circ}$ 毎に発生する分布となることがわかる. 一方, $C>0$ の場合, $C<0$ のときのような分布の特徵は見られない.

また $C<0$ の場合に対して, 最大せん断応力の方向 $\theta^{*}$ は次 式で表される.

$$
\theta^{*}=\frac{1}{2} \cos ^{-1} \frac{1+C}{1-C}+\frac{2 n+1}{4} \pi \quad(n=0,1)
$$

これを図 4 に表示した，なお，図中の $m$ は測定対象とする成 長粒子の個数である. 図から粒子の成長方向 $\theta$ のピーク值と 最大世九断応力の方向 $\theta^{*}$ は，ほぼ一致することがわかる。つ まり，C<0の場合，粒子の成長方向は最大せん断応力の方向 に起こりやすいことがわかった.

次に図 4 の結果をもとに，定量的にCの符号を判定する方 法を検討した. $C<0$ の場合の周期性を表現するために，分布 形を次の関数で近似守る。

$$
f=j \sin \left(\frac{2 \pi}{k} \theta+l\right)+f_{0}
$$

ここで, $f$ は $\theta$ 相対度数, $j$ はピークの高さの約半分（振幅） を表す定数， $k$ はピークの間隔（周期）を表す定数， $l$ は位相 角， $f_{0}$ は縦軸方向への関数の平行移動量である．また図 4(a) には，式(2)により得られる曲線を表示した。図から近似式は $\theta$ の相対分布をうまく表せているとみなせる。

ここでCの符号を判定するのに適したパラメーターはjと $k$ と考えられる. そこでこれらの值を表 2 に示す。 まず $k$ の 值に注目すれば， $C<0$ の場合，ほぼ $90^{\circ}$ に近い値となって いるが, $C>0$ の場合は $90^{\circ}$ とかなり異なる值となっている. また, $j$ の值も $C<0$ の場合は $C>0$ の場合と比べて大きい值 となる. したがって，Cの符号の判定は以下のようになる. まず $k$ の值が $90^{\circ} \pm 10^{\circ}$ の範囲内にあるか確認する。これを 外れるようであれば， $C>0$ と判断できる。 また $C>0$ の場合 でも近似の過程で $k$ の值が偶然 $90^{\circ}$ 程度になる可能性がある. そこで，次にjの值を比較して，表 2 に示すような高い值で あれば $C<0$ であり，そうでなければ $C>0$ と判断できる.

Table2 Experimental coefficients in equation (2)

\begin{tabular}{r|c|r|r|r|r|r}
\hline \hline \multicolumn{2}{c|}{} & \multicolumn{3}{c|}{$C<0$} & \multicolumn{2}{c}{$C>0$} \\
\hline \multirow{2}{*}{$C$} & -1.0 & -0.52 & -0.16 & 0.8 & 1.0 \\
\hline \multirow{3}{*}{$m=50$} & $j$ & 8.95 & 6.89 & 6.79 & 3.27 & 1.99 \\
\cline { 2 - 7 } & $k$ & 98.47 & 88.52 & 80.54 & 172.5 & 53.1 \\
\hline \multirow{3}{*}{$m=100$} & $j$ & 8.64 & 6.41 & 5.54 & & \\
\cline { 2 - 7 } & $k$ & 92.85 & 90.50 & 87.22 & & \\
\hline \multirow{3}{*}{$m=150$} & $j$ & 8.20 & 6.13 & 5.40 & & \\
\cline { 2 - 7 } & $k$ & 96.25 & 84.15 & 87.46 & & \\
\hline
\end{tabular}

\section{参 考 文 献}

（1）大久保肇，銅めつき応力測定法,(1965),朝倉書店.

(2) 北岡征一郎他, 機論, 69-679, A(2003)，565-570

(3) 北岡征一郎他, 機論, 72-720, $\mathrm{A}(2006), 1145-1152$

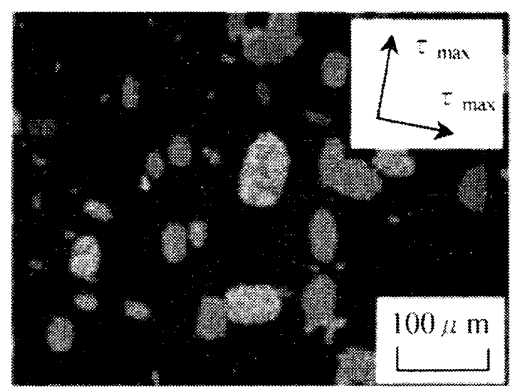

(a) $C=-0.52, \tau_{\max }=60 \mathrm{MPa}$

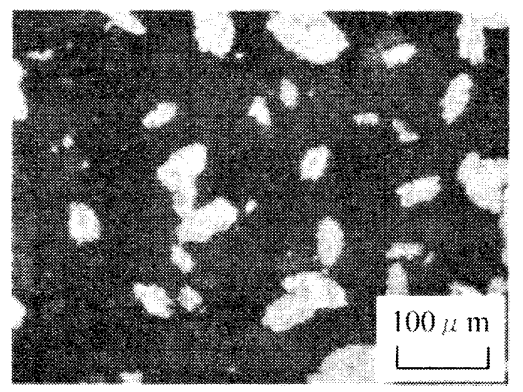

(b) $C=1.0, \tau_{\max }=60 \mathrm{MPa}$

Fig.3 Grown grains occurred at the copper foil

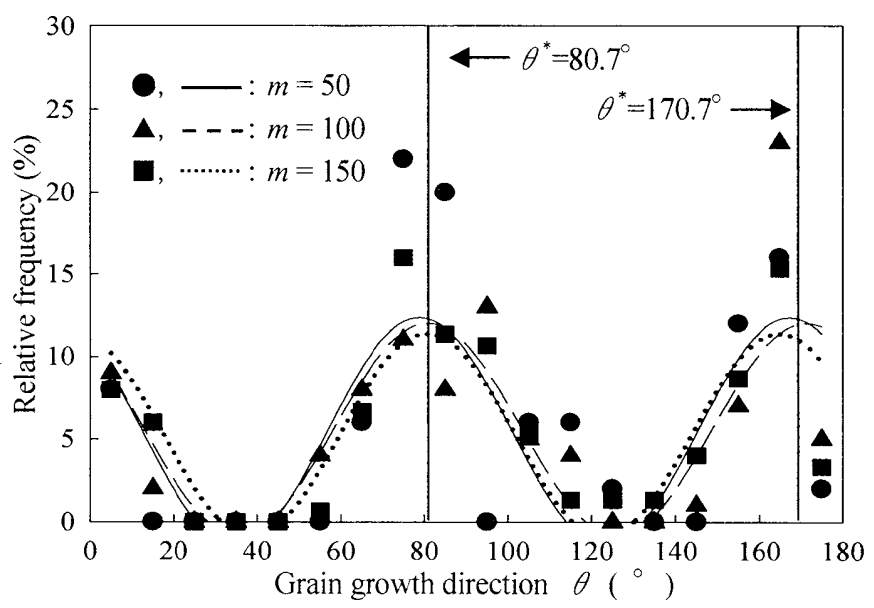

(a) $C=-0.52$

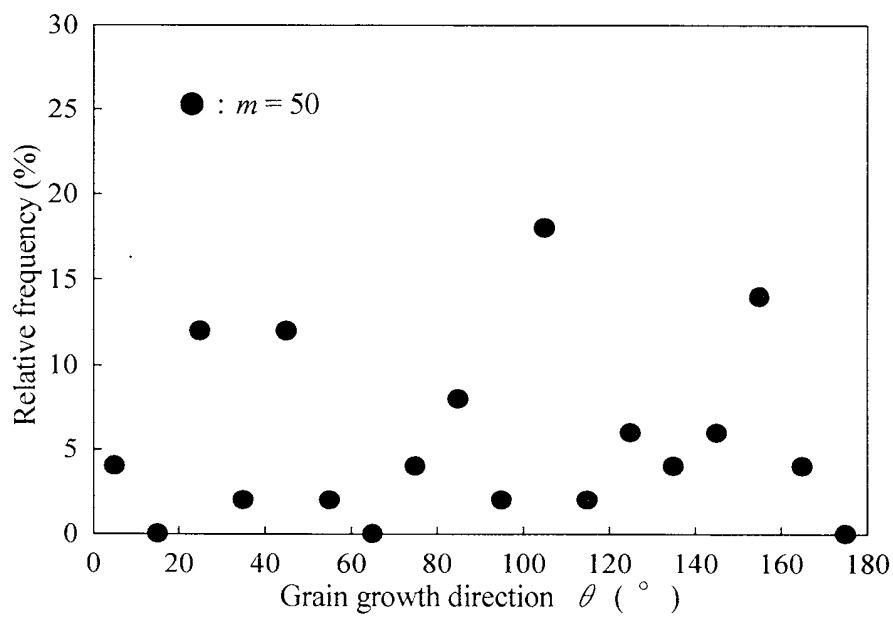

(b) $C=1.0$

Fig.4 Relative frequency diagram of grain growth direction 